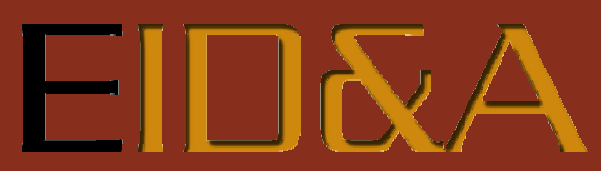

Revista Eletrônica de Estudos Integrados em Discurso e Argumentação

\title{
A CONTRA-ARGUMENTAÇÃO NO DISCURSO POLÍTICO: ANÁLISE DA PRIMEIRA INTERVENÇÃO DE FIDEL CASTRO NA ONU, 1960
}

\author{
Ana Paula Santos de Oliveira ${ }^{i}$ \\ Jacqueline Elizabeth Vásquez Araujo
}

Resumo: O objetivo deste estudo é compreender como a contra-argumentação funciona no discurso político. Para isso, analisamos sequências discursivas da primeira fala de Fidel Castro na Assembleia Geral das Nações Unidas, em 1960. A pesquisa tem como base teórica os estudos sobre conectores discursivos, em especial sobre as partículas opositivas, a teoria da argumentação e o dialogismo bakhtiniano. Nosso principal instrumento de investigação foi a revisão bibliográfica, através de autores como Bakhtin/Volóchinov (2006), Fuentes Rodríguez e Alcaide (2007), García (2007), Montolío (2001), Portolés (1993, 1995, 2001) e Zorraquino e Portolés (1999), entre outros. Em sua conclusão, a pesquisa apontou o grande poder de mobilização da partícula sin embargo, que, no discurso em questão, voltou-se para a persuasão, a explicação refutativa e a substituição. Desses valores, constatamos uma maior recorrência à persuasão.

Palavras-chave: Conectores. Contra-argumentação. Discurso político. Dialogismo.

Abstract: The purpose of this paper is to understand how counter-arguments work in political discourse. We analyze discursive sequences in Fidel Castro's first speech in the 1960 United Nations General Assembly. We use, as theoretical foundations, argumentation theory, Bakhtin's dialogism and studies on discourse connectives, specially opposition elements. Our main investigation method has been bibliographic revision, by examining theorists like Bakhtin/Volóchinov (2006), Fuentes Rodríguez and Alcaide (2007), García (2007), Montolío (2001), Portolés (1993, 1995, 2001), Zorraquino and Portolés (1999), among others. Our findings pointed to a high incidence of mobilization of the linguistic element sin embargo, which was directed to persuasion, refutative explanation and substitution. Among them, the most recurrent one was persuasion.

Keywords: Connectives. Counter-argumentation. Political discourse. Dialogism.

\footnotetext{
' Doutoranda em Linguística pela Universidade Federal de Alagoas (UFAL). Docente do Instituto Federal de Alagoas (IFAL). E-mail: virtual.ana@gmail.com.

ii Doutoranda em Língua Espanhola pela Universidad de Valladolid (UVA). Docente da Universidade Federal de Alagoas (UFAL). E-mail: jvasquezaraujo@gmail.com.
} 
EID\&A - Revista Eletrônica de Estudos Integrados em Discurso e Argumentação, llhéus, n. 15, jan./jun.2018.

\section{Introdução}

Neste estudo, buscamos entender como a contra-argumentação funciona no discurso proferido por Fidel Castro na Assembleia Geral das Nações Unidas, em 26 de setembro de 1960, nos EUA. O objetivo é compreender, a partir da mobilização dos conectores opositivos na fala do então líder cubano, em especial da partícula sin embargo, como a defesa de opinião e a persuasão funcionam no discurso político. Para isso, partimos de três bases teóricas.

Da teoria da argumentação, consideramos a natureza transacional do discurso, através do qual se busca um acordo com o receptor e, por conseguinte, a sua aceitação. "O ato de falar, em si, traz consigo a intenção de convencer e persuadir o destinatário, e de obter sua concordância e colaboração", afirmam Fuentes Rodríguez e Alcaide (2007, p. 11)'.

No que se refere à linguagem, corroboramos com Bakhtin/Volóchinov (2006) quando indica que as formas do signo linguístico dependem da organização social dos indivíduos e das condições em que ocorre a interação verbal. Para o teórico, o locutor se serve da língua para suas necessidades enunciativas concretas, importando para ele não a sua adequação à norma da forma linguística, mas a significação dessa forma quando está inserida em dado contexto.

Já para a análise do funcionamento dos conectores contraargumentativos, partimos da perspectiva de que o significado está sempre em processamento, guiando "as inferências realizadas na comunicação, em conformidade com suas diferentes propriedades morfossintáticas, semânticas e pragmáticas", segundo Zorraquino e Portolés (1999, p. 4.058)². Vale ressaltar que, nesse processo, é necessário considerar, além daquilo que foi dito, o contexto de seus participantes, que "é sempre mental e formado tanto pelas crenças que residem na memória, como também pelas que resultam da percepção imediata da situação ou, simplesmente, do enunciado emitido anteriormente" (ZORRAQUINO; PORTOLÉS, 1999, p. 4.058)3.

\footnotetext{
${ }^{1}$ No original: "El propio acto de hablar lleva consigo la intención de convencer y persuadir al receptor, y de conseguir su acuerdo y su colaboración".

${ }^{2}$ No original: "[...] de acuerdo con sus distintas propiedades morfosintácticas, semánticas y pragmáticas, las inferencias que se realizan en la comunicación.

${ }^{3}$ No original: “[... es siempre mental y está formado por las creencias que residen en la memoria, pero también por aquellas que se derivan de la percepción inmediata de la situación o, simplemente, de lo que se ha dicho antes".
} 
EID\&A - Revista Eletrônica de Estudos Integrados em Discurso e Argumentação, Ilhéus, n. 15, jan./jun.2018.

Personagem controverso da história mundial, Castro mobiliza as partículas opositivas para reforçar o seu discurso e, consequentemente, a legitimidade do governo cubano. Assim, busca persuadir não só a plateia presente à reunião em questão, em um contexto imediato de comunicação, mas a um auditório mais amplo, em termos de opinião pública mundial.

\section{O funcionamento dos marcadores contra-argumentativos}

Para Montólio (2001), a relação lógico-semântica estabelecida entre duas ou mais frases resulta ser uma informação clara quando mediada por elementos especializados em conectar orações. Assim, os conectores funcionam como sinais de localização distribuídos ao longo do discurso para que o leitor percorra sem dificuldades o caminho interpretativo que o autor traça. Este, para evitar que o leitor desvie da trajetória sugerida, vigiará os conectores que utiliza para que expressem exatamente o sentido que the convém, explica a autora.

A capacidade coesiva entre enunciados com vistas a reforçar a coerência textual é critério fundamental na identificação dos conectores, observa García (2007), que os classifica como unidades que estabelecem ligação coesiva com, ao menos, um enunciado anterior. Essa ligação anafórica pode se estender a mais de um enunciado, podendo afetar toda a porção do discurso precedente. A ligação coesiva pode se estender ainda a uma relação catafórica com os enunciados seguintes. No entanto, mesmo nesses casos, a relação anafórica é determinante para que uma unidade seja considerada marcador discursivo, conforme García (2007).

Retomamos Montolío (2001) para destacar que, se de um lado, é inegável que os marcadores pertencentes a diferentes tipos estabelecem relações diferentes, de outro, mesmo os que pertencem a uma mesma família semântica, não são idênticos entre si. Isso ocorre porque seus sentidos não estão ligados diretamente ao léxico. Desse modo, a autora ressalta a necessidade de conhecer o significado e as condições de funcionamento de cada conector, explicando que nem todas as partículas apresentam as mesmas propriedades entoativas, gramaticais e sintáticas. Para explicar a natureza dessa diferença, Montólio (2001) parte de critérios de ordem gramatical, e divide os conectores em parentéticos e integrados à oração. 
EID\&A - Revista Eletrônica de Estudos Integrados em Discurso e Argumentação, llhéus, n. 15, jan./jun.2018.

Enquanto os primeiros se apresentam entre pausas, entre signos de pontuação, o que lhes dá grande mobilidade oracional, os segundos exibem um elemento subordinante em sua formação. No primeiro grupo, estão as partículas sin embargo, además, en consecuencia etc. Após apontar que nem todos os conectores parentéticos possuem a facilidade de mobilidade de sin embargo, Montólio (2001) destaca que, geralmente, eles se combinam com verbos no indicativo. Já os integrados à oração agrupam tanto a conjunção subordinante que (a pesar de que, aunque, para que etc.) quanto as preposições de e a (a pesar de, en caso de, debido a etc.), podendo haver combinação entre ambas (a pesar de que, debido a que etc.). Ao grupo pertencem ainda as conjunções pero, porque, como etc. Além de não possuir a mobilidade do grupo anterior, suas unidades podem ser combinadas com verbos no indicativo e subjuntivo.

No caso dos conectores argumentativos ${ }^{4}$, em especial, seu emprego é mais pertinente em textos expositivos e argumentativos, em detrimento dos narrativos e descritivos. "A função primária dos textos expositivoargumentativos é, de fato, apresentar, razoável e convincentemente, uma série de informações que guiem o leitor para a consecução das conclusões pretendidas", pontua Montolío (2001, p. 43)5. Nesse sentido, é preciso que o autor do texto relacione as orações e os textos de modo a apresentar tanto as causas que conduzem às consequências quanto os possíveis contraargumentos para refutá-los.

Portolés (2001) destaca que os enunciados podem favorecer umas continuações do discurso em detrimento de outras, orientando-se argumentativamente em uma determinada direção. Nesse sentido, o autor apresenta a concepção de "força argumentativa" para dizer que os marcadores opositivos podem carregar uma menor ou maior força. Em seguida, volta-se para a noção de "suficiência argumentativa" para indicar que um enunciado pode apresentar força insuficiente para conduzir a um argumento anti-orientado em relação a outro.

\footnotetext{
4 No plano argumentativo, os conectores estabelecem uma oposição de argumentos; uma conclusão inesperada. (FUENTES RODRIGUES, 2009). Abrangem os aditivos, os de causalidade e os opositivos (GARCÍA, 2007).

${ }^{5}$ No original: "En efecto, la función básica de los textos expositivo-argumentativos es presentar una serie de informaciones de manera razonable y convincente, a fin de conducir al lector a las conclusiones que interesan".
} 
EID\&A - Revista Eletrônica de Estudos Integrados em Discurso e Argumentação, Ilhéus, n. 15, jan./jun.2018.

Considerando que há autores que empregam essa menor ou maior força argumentativa como critério distinguidor de relações concessivas e adversativas, ambas inseridas no grupo das relações opositivas de contraargumentação, sendo adversativo o conector que introduz o enunciado de maior força argumentativa, e concessivo, o que introduz o enunciado de menor força, García (2001) ressalva que esse não é o melhor critério para especificar as relações adversativas e concessivas, pois ele não dá conta da abordagem do conetor aunque.

Em seu lugar, propõe um critério centrado em dois tipos de contraargumentação: a direta, quando a conclusão do primeiro enunciado é anulada pelo conteúdo do segundo; e a indireta, quando a conclusão do primeiro enunciado é cancelada pela conclusão do segundo. Segundo esse critério, a contra-argumentação direta seria característica da relação concessiva, podendo ser introduzida por pero, aunque, sin embargo, con todo etc., com algumas unidades podendo indicar relações tanto adversativas quanto concessivas (pero, aunque e sin embargo).

No presente estudo, mapeamos os conectores contra-argumentativos mais recorrentes na intervenção de Fidel Castro. Desse modo, identificamos as unidades pero, que aparece 49 vezes; sin embargo, 22 vezes; sino (que), 16 vezes; aunque, 8 vezes. Outros conectores ocorrem em menor frequência, a exemplo do conector en cambio ( 3 ocorrências) e dos conectores ahora e eso sí, registrados uma única vez. De posse desses dados, decidimos trabalhar com um de seus conectores - a partícula sin embargo. A escolha é de cunho teórico. $\mathrm{Na}$ literatura especializada sobre marcadores discursivos, sin embargo é considerado o protótipo da categoria dos contra-argumentativos (ZORRAQUINO; PORTOLÉS, 1999, p. 4.115; SANCHEZ, 2007, p. 39).

Em termos gerais, o conector sin embargo é um elemento genérico, semelhante aos valores de en cambio, no obstante, por el contrario, con todo, ahora bien, e pode ser usado para assinalar oposição de segmentos contrários, oposição de força argumentativa, relevância informativa ou valor concessivo (FUENTES RODRÍGUEZ, 2009). De outra parte, García (2007) destaca que, embora a unidade sin embargo seja, tradicionalmente, apresentada como semelhante a no obstante, sobretudo porque compartilham o significado de obstáculo, podem-se estabelecer diferenças entre ambas as partículas, a saber: a capacidade de sin embargo aparecer em textos refutativos, o que não ocorre com no obstante, e em um contexto de contraste. 
EID\&A - Revista Eletrônica de Estudos Integrados em Discurso e Argumentação, llhéus, n. 15, jan./jun.2018.

\section{A contra-argumentação no discurso político: Análise da fala de Fidel Casto}

Para compreender o funcionamento da contra-argumentação no discurso político, elegemos como corpus de estudo o primeiro discurso de Fidel Castro na Assembleia Geral da ONU, ocorrido em 26 de setembro de 1960. A escolha se deu em virtude da forte presença das partículas em questão na fala do então líder cubano, famoso por proferir longos discursos.

Sempre falando em terceira pessoa, de modo a ocupar o lugar de portavoz do povo cubano e também dos povos dos países subdesenvolvidos, Fidel Castro inicia seu discurso destacando o seu objetivo na reunião: expor os problemas de Cuba decorrentes da revolução de 1959, que derrubou o governo de Fulgencio Batista, presidente eleito de Cuba entre 1940 e 1944 e ditador entre 1953 e 1959, com o apoio do governo dos EUA.

Na sequência discursiva seguinte (SD, nas colocações seguintes), ele discorre acerca da recepção à delegação cubana em Nova York, nos EUA, por ocasião da reunião da ONU:

SD1 - ¿Seremos nosotros, los de la delegación cubana, la representación del tipo de gobierno peor del mundo? ¿Seremos nosotros, los representantes de la delegación cubana, acreedores al maltrato que hemos recibido? ¿Y por qué precisamente nuestra delegación? Cuba ha enviado muchas delegaciones a las Naciones Unidas, Cuba ha estado representada por diversas personas y, sin embargo, nos correspondieron a nosotros las medidas de excepción: confinamiento a la Isla de Manhattan, consigna en todos los hoteles para que no se nos alquilasen habitaciones, hostilidad y, bajo el pretexto de la seguridad, el aislamiento. (CASTRO, 1960, on-line, destaque nosso).

O líder cubano inicia sua intervenção apresentado uma série de argumentos acerca do tema que expõe - a má recepção da delegação cubana nos EUA. Na sequência, é possível apreender o lugar em que ele se coloca e coloca o outro, personagem principal de sua fala, apontado como a causa dos problemas cubanos. Marco forte de sua argumentação, Fidel pontua que, embora Cuba tenha enviado, em anos anteriores, antes da revolução, inúmeras delegações àquela reunião, sem sofrer restrições, o mesmo não ocorria com a sua delegação:

SD1 - Cuba ha enviado muchas delegaciones a las Naciones Unidas, Cuba ha estado representada por diversas personas y, sin embargo nos correspondieron a nosotros las medidas de excepción [...] (CASTRO, 1960, on-line, destaque nosso). 
EID\&A - Revista Eletrônica de Estudos Integrados em Discurso e Argumentação, Ilhéus, n. 15, jan./jun.2018.

Lembrando que sin embargo apresenta maior mobilidade oracional, característica dos conectores parentéticos (MONTÓLIO, 2001), vemos que, na SD1, essa unidade introduz um enunciado que rompe com a inferência a que conduz o primeiro membro da proposição, ou seja, que, assim como aconteceu com as delegações anteriores, esperava-se que a delegação da reunião de 1960 recebesse o mesmo tratamento dispensado àquelas, o que não ocorreu. Nesse sentido, destaca-se o papel funcional restritivo da partícula sin embargo.

Assim, sin embargo demarca uma conclusão anti-orientada (PORTOLÉS, 2001) em relação à orientação argumentativa do enunciado que a precede: Cuba ha enviado muchas delegaciones a las Naciones Unidas, Cuba ha estado representada por diversas personas. Com isso, Fidel tenta persuadir a plateia quanto à quebra de um protocolo, já que Cuba foi a única delegação a sofrer restrições, apesar da experiência do país no campo diplomático.

$\mathrm{Na}$ SD2, é mais enfático quanto ao tratamento recebido por Cuba nos EUA. Ademais, aproveita a ocasião para falar sobre os ataques que seu país estaria sofrendo nos meios de comunicação norte-americanos. Na sequência abaixo, ele lança outra série de argumentos:

SD2 - Tratos personales vejaminosos, intentos de extorsión, desalojo del hotel en que residíamos, y cuando marchamos hacia otro hotel hemos puesto de nuestra parte todo lo posible para evitar dificultades, absteniéndonos por completo de salir de nuestro alojamiento, no asistiendo a ningún otro punto que a esta sala de las Naciones Unidas, las contadas veces que hemos asistido, y la aceptación a una recepción en la embajada del gobierno soviético. Sin embargo, eso no bastó para que nos dejaran en paz. (CASTRO, 1960, on-line, destaque nosso).

Na passagem, é possível observar que Castro faz movimentar outros argumentos com vistas a ganhar a adesão de seus interlocutores. Nela, a unidade em análise não mais se apresenta entre vírgulas, como em SD1. Isso se deve ao grande poder de mobilidade de sin embargo, como já destacamos. Mas, ambas as sequências apresentam um mesmo efeito de sentido persuadir -, estando anti-orientadas em relação aos enunciados antecedentes.

O mesmo ocorre na SD3, por meio da qual Castro muda o tema de seu discurso, apontando para o aumento da criminalidade entre os cubanos que residiam nos EUA, causada, segundo ele, pelos cubanos que haviam emigrado para aquele país como "criminosos de guerra". Adiante, o cubano aborda a morte de uma menina, que, conforme o que pode ser apreendido de sua fala, fora atribuída, de forma equivocada, aos cubanos residentes nos EUA: 
EID\&A - Revista Eletrônica de Estudos Integrados em Discurso e Argumentação, llhéus, n. 15, jan./jun.2018.

SD3 - Uno de esos incidentes, provocado por los que aquí se sienten respaldados por las campañas sistemáticas contra Cuba, y por la complicidad de las autoridades, dio lugar a la muerte de una niña. Ese hecho era de lamentar, y era para que lo lamentásemos todos. Los culpables no eran, precisamente, los cubanos residentes aquí. Los culpables no éramos, mucho menos, nosotros, los de la delegación cubana y, sin embargo, seguramente todos ustedes habrán visto esos cintillos de los periódicos donde se hablaba de que "Grupos Pro Castro" habían dado muerte a una niña de 10 años. (CASTRO, 1960, on-line, destaque nosso).

Introdutor de argumentos fortes, a partícula sin embargo se comporta no sentido de reforçar a posição de não participação de Cuba na morte da menina - Los culpables no eran, precisamente, los cubanos residentes aquí, esclarece Castro, que, no enunciado seguinte, enfatiza: Los culpables no éramos, mucho menos, nosotros, los de la delegación cubana. No mesmo enunciado, ele também faz uso do conector para reforçar a sua posição a respeito da campanha dos meios de comunicação contra Cuba. Ainda na SD3, o membro oracional em que está localizada sin embargo aponta para uma conclusão antiorientada à posição do outro referido por Fidel. Quanto ao contexto situacional da sua fala, é necessário ter em mente que seus interlocutores não precisavam se esforçar para apreender os sentidos dela decorrentes, pois todas as lideranças presentes estavam cientes do conflito envolvendo Cuba e EUA $^{6}$.

Assim, corroboramos com Bakhtin/Volóchinov (2006, p. 132) quando diz que "Se perdermos de vista os elementos da situação, estaremos tão pouco aptos a compreender a enunciação como se perdêssemos suas palavras mais importantes". Para o teórico, o tema da enunciação, como se referia ao sentido da enunciação completa, é determinado pelas formas linguísticas e pelos elementos não verbais da situação. Assim, observa que o tema da enunciação é "tão concreto como o instante histórico ao qual ela pertence", e que só "a enunciação tomada em toda a sua amplitude concreta, como fenômeno histórico, possui um tema" (BAKHTIN/VOLÓCHINOV, 2006, p. 132).

Já na SD4, o funcionamento do conector sin embargo, mais do que se voltar para a persuasão, procura explicar, com base na exposição de informações, os problemas enfrentados por Cuba no período pós-revolução.

\footnotetext{
${ }^{6}$ Para Fuentes Rodríguez, essa conexão entre os fatos ou conceitos que a comunidade socializou permite que sejam relacionados os argumentos que conduzem a uma conclusão. É o que a autora chamou, seguindo a Ducrot, topos ou relação argumentativa, ou ainda "ley de paso"; "un conocimiento consabido por los participantes en la comunicación (FUENTES RODRíGUEZ, 2007, p. 36).
} 
EID\&A - Revista Eletrônica de Estudos Integrados em Discurso e Argumentação, llhéus, n. 15, jan./jun.2018.

Nesse sentido, trazemos Montolío (2001) para destacar que, embora pertença a uma mesma família semântica, um mesmo conector pode estabelecer relações diferentes em suas colocações, não sendo, pois, idênticos entre si. $\mathrm{Na}$ sequência, Castro, finalmente, explícita a quem suas criticas são direcionadas. Adiante, retoma o tema do tratamento dado à comitiva cubana em sua passagem pelos EUA.

SD4 - Pero eso no era todo. Cuando nosotros fuimos obligados a abandonar uno de los hoteles de esta ciudad, y nos dirigimos hacia la sede de las Naciones Unidas, mientras se hacían otras gestiones, hay un hotel, un hotel humilde de esta ciudad, un hotel de los negros de Harlem, que nos dio alojamiento. La respuesta llegó mientras nosotros conversábamos con el señor Secretario General. Sin embargo, un funcionario del Departamento de Estado hizo todo lo posible por impedir que nosotros nos alojásemos en ese hotel. (CASTRO, 1960, on-line, destaque nosso).

Sem o mesmo poder de persuasão das sequencias anteriores, a SD4 visa explicar um episódio que envolvia a estada da delegação cubana em Nova York. Nela, Fidel Castro pontua que, após inúmeras tentativas de conseguir hospedagem, um hotel pobre, localizado em um bairro de negros, havia aceitado hospedar os cubanos. Com base nessa colocação, podemos inferir que a questão estava, por fim, solucionada. Porém, esse sentido é descontruído a partir da introdução do conector sin embargo no enunciado seguinte, desfazendo, assim, a orientação argumentativa do segmento anterior. Fidel conclui sua fala destacando a hostilidade com que a delegação cubana foi recebida. Dessa forma, coloca os EUA como os vilãos e Cuba como a parte injustiçada. A seguir, a próxima sequência apresenta a mesma direção de sentidos da SD4, visto que ambas se voltam para a explicação, em detrimento da persuasão, introduzindo, com a unidade sin embargo, argumentos anti-orientados aos enunciados anteriores.

SD5 - No cayó una manzana, cayeron varias manzanas en sus manos. Cayó Puerto Rico, el heroico Puerto Rico que había iniciado su lucha por la independencia junto con los cubanos; cayeron las Islas Filipinas, y cayeron varias posesiones más. Sin embargo, el expediente para dominar nuestro país no podía ser el mismo. Nuestro país había sostenido una tremenda lucha y a su favor existía la opinión del mundo. El expediente debía ser distinto. (CASTRO, 1960, on-line, destaque nosso).

Na SD5, Castro apresenta um novo tema: o processo de independência de Cuba e as relações estabelecidas com os EUA desde então. Mencionando um ex-presidente americano, ele observa que Cuba era uma maçã prestes a cair da árvore espanhola nas mãos dos EUA. Utilizando-se da mesma 
EID\&A - Revista Eletrônica de Estudos Integrados em Discurso e Argumentação, Ilhéus, n. 15, jan./jun.2018.

metáfora, indica que várias maçãs caíram nas mãos desse país, como Porto Rico e Filipinas. Mais adiante, indo de encontro à inferência determinada pelo discurso anterior, eliminando, assim, a sua conclusão, ressalta que - Sin embargo, el expediente para dominar nuestro país no podía ser el mismo. Tal é a função da unidade em estudo: suprimir inferências que poderiam ser deduzidas de um enunciado anterior (PORTOLÉS, 1993).

Ao concluir sua fala, o representante cubano traz a imagem de uma Cuba valente, cujo povo lutou 30 anos para se tornar independente da Espanha. Nuestro país había sostenido una tremenda lucha y a su favor existía la opinión del mundo, expõe Castro, que constrói uma segunda imagem da opinião pública mundial quando se volta para o período que abrangeu o processo de descolonização de Cuba. El expediente debía ser distinto, conclui. Em seguida, ele faz uma longa explanação sobre a independência de Cuba (1902) até a revolução de 1959, com ênfase na influência dos EUA nos dois episódios. Na SD6, destaca o final da revolução:

SD6 - Incluso cuando el Ejército Rebelde llega a la ciudad de La Habana, en el campamento militar más importante de esa ciudad estaba la misión militar norteamericana. Aquel era un ejército que había colapsado, aquel era un ejército vencido y rendido. Nosotros pudimos considerar perfectamente como prisioneros de guerra a aquellos militares extranjeros que estaban allí ayudando y entrenando a los enemigos del pueblo. Sin embargo, esa no fue nuestra actitud; nuestra actitud se limitó a pedirles a los miembros de esa misión que regresasen a su país, que, después de todo, nosotros no necesitábamos sus lecciones, y que allí sus discípulos estaban vencidos. (CASTRO, 1960, on-line, destaque nosso).

Como nas sequências anteriores, a SD6 comprova o que Montolío (2001) indica, a saber, que a partícula sin embargo é especialista em unir segmentos constituídos por mais de uma oração, além da sua capacidade de aparecer tanto em textos refutativos quanto em contextos de contraste. Como nas sequências anteriores, a SD6 aponta para a refutação dos segmentos precedentes. Assim, após explicitar as circunstâncias da rendição dos soldados dos EUA em Cuba - Aquel era un ejército que había colapsado, aquel era un ejército vencido y rendido -, o líder cubano esclarece, na mesma sequência, que o exército cubano poderia considerar perfectamente como prisioneros de guerra a aquellos militares extranjeros que estaban allí ayudando y entrenando a los enemigos del pueblo. Dessa maneira, apresenta uma prática recorrente nos conflitos em geral: fazer dos perdedores prisioneiros de guerra. 
EID\&A - Revista Eletrônica de Estudos Integrados em Discurso e Argumentação, llhéus, n. 15, jan./jun.2018.

No entanto, Fidel Castro rompe com essa inferência, trazendo, em seu lugar, um sentido outro, anti-orientado em relação ao discurso anterior. Sin embargo, esa no fue nuestra actitud, afirma. Com isso, reforça a imagem de Cuba como nação pacífica, cujos interesses se voltavam unicamente para o bem-estar do seu povo. Foi para isso que lutaram; e não para se vingar. Eis a mensagem que Fidel Castro tenta passar na conclusão da SD6.

O representante cubano aborda ainda as primeiras medidas tomadas pelo governo revolucionário, como a diminuição dos preços dos aluguéis e das tarifas elétricas, a anulação de leis relacionadas a concessões de uso da telefonia e a reforma agrária, que contrariavam, segundo Fidel, os interesses dos EUA. Voltando-se à Primeira Guerra Mundial (1914-18), o cubano destaca as rígidas exigências impostas pelos EUA em relação à produção de açúcar no país desde então. A situação continuou até a década de 30, continua. É o que traz a SD7:

SD7 - Y así prosiguió esa situación, hasta la década del 30 y el gobierno de Estados Unidos, tratando de encontrar una fórmula que conciliara sus intereses de abastecimiento con los intereses de sus productores internos, establece un régimen de cuotas, esa cuota se suponía que tendría por base la participación histórica que hubiesen tenido en el mercado las distintas fuentes de abastecimiento y en que nuestro país había tenido una participación histórica de casi un $50 \%$ en el abastecimiento del mercado norteamericano. Sin embargo, cuando se establecieron las cuotas, nuestra participación quedó reducida a un $28 \%[\ldots]$. (CASTRO, 1960, on-line, destaque nosso).

No primeiro enunciado da SD7, Fidel apresenta a razão que desencadeou a rebelião cubana. Com isso, procura convencer a plateia quanto à legitimidade da revolução de 1959. Centrada na exploração econômica imposta a Cuba pelos EUA, a premissa aponta que, antes do regime de cotas, - açúcar cubano havia alcançado a marca histórica de quase 50\% de abastecimento nos EUA. No enunciado seguinte, introduzido pela partícula sin embargo, o líder cubano afirma que a participação do açúcar cubano naquele país caiu consideravelmente com as cotas. Funcionando no sentido de comparar duas fases da comercialização do açúcar de Cuba no mercado norteamericano, o conector em questão não se volta para a eliminação da inferência do primeiro discurso, ou numa quebra de linearidade, mas na substituição entre uma situação anterior e uma etapa posterior. Nesse sentido, funciona de modo distinto das sequências discursivas anteriores, pois seu foco não é persuadir nem explicar uma situação. 
EID\&A - Revista Eletrônica de Estudos Integrados em Discurso e Argumentação, Ilhéus, n. 15, jan./jun.2018.

Dando continuidade à problemática envolvendo o açúcar cubano, Fidel Castro destaca os incêndios provocados por aviões de procedência dos EUA nos canaviais de Cuba e o convênio comercial estabelecido com a URSS em vista dos prejuízos advindos da política norte-americana com relação à produção açucareira.

SD8 - La agresión económica, como lo saben todos los delegados aquí de América Latina, está expresamente condenada por el Derecho Internacional Regional. Sin embargo, el gobierno de Estados Unidos viola ese derecho, esgrime el arma económica, nos arrebata de nuestra cuota azucarera casi un millón de toneladas, y nada más. Ellos lo podían hacer. (CASTRO, 1960, on-line, destaque nosso).

Nessa passagem, Fidel Castro volta a estabelecer a contra-argumentação nos moldes anteriores a SD7, isto é, demarcando um espaço de significação não-linear, que rompe com a orientação argumentativa do primeiro enunciado. Assim, põe em funcionamento, através unidade sin embargo, outra ordem enunciativa, que suscita, pois, outro efeito de sentido.

Em sua fala, Fidel utiliza palavras e expressões de forte poder persuasivo, revelando uma mudança de sentido em seu discurso, que passa de um tom mais ameno para um mais desafiador, com ataques diretos aos EUA. São os próprios elementos linguísticos, diz Portolés (2001), que encaminham a argumentação. Não se argumenta com a língua, mas na língua, diz.

$\mathrm{Na}$ conclusão da SD8, Castro anuncia: Ellos lo podían hacer. Com isso, sinaliza a ausência de neutralidade do direito internacional em relação aos embates econômicos entre Cuba e EUA. Assim, volta-se tanto contra estes quanto contra o organismo internacional, que lava suas mãos diante da situação, segundo o que deduzimos de sua fala. El gobierno de Estados Unidos viola ese derecho, esgrime el arma económica, nos arrebata de nuestra cuota azucarera casi un millón de toneladas, y nada más (destaque nosso), argumenta Fidel Castro.

Na próxima sequência, o representante de Cuba trata de um episódio que envolveu a URSS, acusada de interferir na política da Costa Rica:

SD9 - No fue condenado el gobierno de Estados Unidos por las 60 incursiones de aviones piratas, no fue condenado por la agresión económica y por otras muchas agresiones. No. Condenaron a la Unión Soviética. ¡Qué cosa tan extraordinaria! Nosotros no habíamos recibido ninguna agresión de la Unión Soviética; ningún avión soviético había volado sobre nuestro territorio, y, sin embargo, en Costa Rica condenan a la Unión Soviética por intromisión. (CASTRO, 1960, on-line, destaque nosso). 
EID\&A - Revista Eletrônica de Estudos Integrados em Discurso e Argumentação, Ilhéus, n. 15, jan./jun.2018.

Na SD9, Castro utiliza como argumento, ante a condenação da URSS em Costa Rica, o fato de que os EUA, embora tivessem agredido Costa Rica em vários aspectos, não haviam sido condenados. Desse modo, aponta o tratamento desigual dispensado aos dois países. No primeiro enunciado, relaciona mais argumentos para destacar a proteção recebida pelos EUA na Costa Rica: 1) No fue condenado el gobierno de Estados Unidos por las 60 incursiones de aviones piratas; 2) por la agresión económica; 3) y por otras muchas agresiones. Em seguida, Castro ressalta: Condenaron a la Unión Soviética. ¡Qué cosa tan extraordinaria!

Ao fazer uso da entonação, indicada pelos pontos de exclamação, Castro mostra a sua indignação quanto ao tratamento dado aos EUA e URSS na Costa Rica. A esse respeito, vale destacar a discussão que Bakhtin/Volóchinov (2006) traz entre significação, ou aparato técnico utilizado para a realização do tema (sentido), e a apreciação. Para o teórico, toda palavra usada na fala real possui, além de tema e significação, um acento apreciativo, ou de valor.

O nível mais superficial da apreciação social contida na palavra é transmitido por meio da entonação expressiva, determinada, na maioria dos casos, pela situação imediata, explica Bakhtin/Volóchinov (2006).

No último argumento, Fidel Castro usa sin embargo para ressaltar que, apesar da não agressão cometida pela URSS a Costa Rica, esta a condenava por "intromissão". Aqui, pode-se inferir que a imagem que o líder cubano constrói da URSS é semelhante à imagem que ele apresenta de Cuba; trata-se de nações pacíficas, que, sensíveis aos problemas enfrentados na América Latina, causados pelos EUA, são constantemente agredidas pelo governo deste país.

Mais adiante, o líder cubano lê trechos de duas notas enviadas pelo governo de Cuba ao governo dos EUA, que comprovaria o esforço daquele em manter boas relações com o último. A SD10 traz um trecho da segunda nota, datada de 22 de fevereiro de 1960:

SD10 - "El Gobierno Revolucionario de Cuba desea aclarar, sin embargo, que la reanudación y desenvolvimiento ulterior de dichas negociaciones, tienen necesariamente que estar supeditadas a que por el gobierno o el Congreso de vuestro país, no se adopte medida alguna de carácter unilateral que prejuzgue los resultados de las negociaciones antes mencionadas o que pueda irrogar perjuicios a la economía o al pueblo cubano." (CASTRO, 1960, on-line, destaque nosso). 
EID\&A - Revista Eletrônica de Estudos Integrados em Discurso e Argumentação, Ilhéus, n. 15, jan./jun.2018.

Na sequência, Castro ressalta a boa vontade do governo cubano para com os EUA. A partir de suas colocações, inferimos, considerando o que já foi explicitado sobre a política externa norte-americana, que a unidade sin embargo conduz ao entendimento de que os EUA não aceitavam o diálogo em sua política externa, agindo de forma unilateral. Logo, sin embargo funciona como partícula contra-argumentativa na SD10. Nem sempre a relação argumentativa é estabelecida entre dois enunciados, pois um deles pode estar implícito, dizem Fuentes Rodríguez e Alcaide (2007), que partem do princípio da acessibilidade ao apontar que o receptor deve dispor de informação suficiente para acessar uma conclusão implícita.

Em seguida, depois de acusar o governo norte-americano de violar todos os convênios internacionais em relação a Cuba, como a violação de seu espaço aéreo, Fidel Castro critica o estabelecimento de bases navais dos EUA no território cubano. A esse respeito, destaca:

\begin{abstract}
SD11 - Una base naval en el territorio de cualquier país es motivo de justa preocupación. Primero, la preocupación de que un país que mantiene una política internacional agresiva y guerrerista es poseedor de una base allí en el corazón de nuestra isla, que hace a nuestra isla correr los peligros de cualquier conflicto internacional, de cualquier conflicto atómico, sin que nosotros tengamos absolutamente nada que ver con el problema, porque nosotros no tenemos absolutamente nada que ver con los problemas del gobierno de Estados Unidos y con las crisis que provoca el gobierno de Estados Unidos. Y, sin embargo, hay una base allí en el corazón de nuestra isla que entraña para nosotros un peligro en el caso de cualquier contingencia bélica. (CASTRO, 1960, on-line, destaque nosso).
\end{abstract}

Na SD11, Castro inicia sua fala ressaltando que uma base naval é motivo de justa preocupação para qualquer país. A partir dessa argumentação, situa o problema em questão: o perigo que representava a presença de uma base naval dos EUA em Cuba. Ressaltando o poderio bélico daquele país, o líder cubano utiliza outro argumento para persuadir a plateia de que a base não tinha permissão para funcionar. Assim, Fidel Castro utiliza sin embargo, que surge entre vírgulas e antecedida da conjunção "y", estabelecendo um laço de coordenação aditiva com o primeiro enunciado (SANTOS RíO, 2003), a fim de ressaltar que, apesar de representar um perigo para Cuba, o governo dos EUA insistia em manter a base naval na ilha.

Já na SD15, Fidel Castro se volta para o então candidato à presidência dos EUA John Kennedy, a quem acusa de ter dado declarações acerca do uso da Organização dos Estados Americanos (OEA) pelos EUA para impedir 
EID\&A - Revista Eletrônica de Estudos Integrados em Discurso e Argumentação, llhéus, n. 15, jan./jun.2018.

qualquer ação do governo de Cuba em outros governos latino-americanos e da possível interferência da URSS em Cuba, no sentido de converter a ilha em sua base no Caribe. Na mesma sequência, além de criticar Kennedy, Castro também se volta contra Richard Nixon, outro candidato à presidência dos EUA:

SD12 - De todos modos, es desalentador, y nadie piense, sin embargo, que estas opiniones sobre las declaraciones de Kennedy indiquen que nosotros sentimos ninguna simpatía por el otro, el señor Nixon (RISAS), que ha hecho unas declaraciones similares. Para nosotros, los dos carecen de seso político. (CASTRO, 1960, on-line, destaque nosso).

$\mathrm{Na}$ sequência, o líder cubano considera o que seus interlocutores poderiam inferir em relação à sua posição quanto à campanha presidencial dos EUA, que ocorreria em menos dois meses: que a crítica a Kennedy significaria apoio a Nixon. Nesse sentido, sin embargo institui uma contraargumentação ao que poderia inferir a plateia de Castro. Em seguida, Fidel Castro explicita que os problemas que afetam Cuba também atingem outros países. Além de mencionar países da América Latina, como Panamá, Porto Rico e Honduras, o líder cubano também menciona países africanos (Congo, Egito, Argélia) e asiáticos (Irã ocidental):

SD13 - Sin embargo, el caso de Cuba no es un caso aislado. Sería un error pensar en el caso de Cuba. El caso de Cuba es el caso de todos los pueblos subdesarrollados. (CASTRO, 1960, on-line, destaque nosso).

Colocada no início da SD13, a unidade sin embargo conduz ao entendimento de que os problemas levantados por Castro em seu discurso também eram os mesmos enfrentados pelos países subdesenvolvidos, de modo geral. Dessa maneira, colocar-se no lugar de seus interlocutores, que poderiam inferir que ele estaria interessado só em defender o seu governo. Logo, Castro introduz, por meio do conector sin embargo, uma argumentação anti-orientada com respeito à possível determinação argumentativa do auditório presente à reunião da ONU.

Ademais, busca descolar Cuba da imagem dos EUA, cujo governo é representado como agressivo, egoísta, enquanto aquela é representada como a parte injustiçada, que, apesar das agressões sofridas, sensibiliza-se com os países que compartilham dos mesmos problemas cubanos - El caso de Cuba es el caso de todos los pueblos subdesarrollados, observa. 
EID\&A - Revista Eletrônica de Estudos Integrados em Discurso e Argumentação, llhéus, n. 15, jan./jun.2018.

Na SD14, Fidel Castro aborda o problema da Argélia, cujo povo lutava pela independência. Dirigindo suas críticas aos países que mantiveram colônias no passado, em especial, a França, que insistia em manter a Argélia sob domínio, Castro sai em defesa do país africano, ressaltando que, assim como França pertencia à Europa, Argélia fazia parte da África.

\begin{abstract}
SD14 - Hace varios años que, sin embargo, ese pueblo africano libra una lucha heroica contra la metrópoli. Quizás mientras nosotros estamos discutiendo aquí tranquilamente, sobre aldeas y pueblos argelinos estén cayendo la metralla y las bombas del gobierno o del ejército francés. $Y$ están muriendo los hombres, en una lucha donde no hay la menor duda respecto al lado de quien está el derecho y que puede resolverse tomando en cuenta incluso los intereses de una minoría, que es la que se toma también como pretexto para negarles el derecho a la independencia a las nueve décimas partes de la población de Argelia. Sin embargo, no hacemos nada. (CASTRO, 1960, on-line, destaques nosso).
\end{abstract}

Na sequência, Fidel Castro usa o conector sin embargo em duas ocasiões. Na primeira, para ressaltar que, embora o povo da Argélia lutasse há anos para se libertar da França, como pode ser apreendido do enunciado que inicia a SD14, e essa luta fosse justa, o objetivo não foi alcançado. Desse modo, sin embargo rompe com a cadeia linear que levaria à conclusão de que Argélia não precisaria lutar para ser livre, visto que esse é um direito que assiste a todo povo.

Até o momento, a análise de todas as sequências vai ao encontro do que diz García (2007), segundo a qual os conectores são unidades que estabelecem ligação coesiva com ao menos um enunciados anterior, podendo essa ligação anafórica se estender a mais de um enunciado. É o que acontece com a segunda partícula sin embargo da SD14. Em seu discurso, Castro remete a uma provável situação na Argélia no momento em que discursava.

Através de suas colocações, busca situar o auditório quanto à gravidade do problema na Argélia. Assim, quando enfatiza que o povo argelino estava morrendo enquanto todos discutiam, tranquilos, na reunião da ONU, e que não havia dúvidas de que lado o direito estava no conflito, tenta persuadir, de forma indireta ${ }^{7}$, os representantes presentes a ajudarem Argélia. O conector sin embargo reforça essa mensagem quando indica no hacemos nada.

\footnotetext{
${ }^{7}$ Em seu estudo sobre a contra-argumentação em língua escrita, Silva Fernandes (2005), analisando artigos de jornais espanhóis e brasileiros, relata a funcionalidade de sin embargo como introdutor de contra-argumentações também indiretas, além das diretas marcadas pela literatura sobre o tema (Portolés, 1995). Essa autora sustenta a funcionalidade dupla de sin embargo explicando que "lo que existe es una tendencia de uso que sufre una variación según el contexto, la intención del locutor y el estilo de argumentación de cada idioma” (SILVA FERNANDES, 2005, p. 243).
} 
EID\&A - Revista Eletrônica de Estudos Integrados em Discurso e Argumentação, llhéus, n. 15, jan./jun.2018.

Encaminhando-se para o final da sua intervenção, Fidel inclui um novo tema em sua fala: a ausência da China da reunião. Criticando a ONU, que estaria negando a sua razão de ser ao não permitir, ao menos, a discussão do problema, ressalta que a ausência da China se devia ao governo dos EUA. Na mesma fala, observa que, por outro lado, os representantes da Espanha, então sob o domínio da ditadura de Francisco Franco, participavam da assembleia.

Adiante, faz uma consideração sobre o surgimento das Nações Unidas:

SD15 - Surgen después de la lucha contra el fascismo, después que decenas de millones de hombres murieron. Y así, de aquella lucha que tantas vidas costó, surgió esta organización como una esperanza. Sin embargo, hay extraordinarias paradojas: cuando los soldados norteamericanos caían en Guam, o en Guadalcanal, o en Okinawa, o en una de las muchas islas de Asia, caían también en el territorio continental chino, luchando contra el mismo enemigo, esos mismos hombres a quienes se les niega el derecho a discutir su ingreso en las Naciones Unidas. Y, mientras al mismo tiempo soldados de la División Azul luchaban en la Unión Soviética en defensa del fascismo, a la República popular China se le niega el derecho a que se discuta su caso aquí, en las Naciones Unidas. (CASTRO, 1960, on-line, destaque nosso).

No primeiro enunciado, Fidel Castro destaca que a ONU surgira como uma esperança, conduzindo ao entendimento de que, com o seu advento, o mundo caminharia para um clima de paz. Porém, Castro rompe com essa linearidade quando observa, a partir da utilização da partícula sin embargo, os "extraordinários paradoxos" surgidos com as Nações Unidas. Dessa forma, constrói um argumento anti-orientado ao discurso anterior. Para isso, justifica o seu posicionamento por meio da comparação com respeito à participação dos soldados dos EUA, da China e da Espanha durante a segunda guerra. Primeiro, observa que tanto os soldados dos EUA quanto os da China morreram em um conflito lutando contra um mesmo inimigo.

Entendendo que a intenção de Fidel Castro é reafirmar a injustiça cometida pela ONU em não aceitar a China como membro, visto que seus soldados lutaram ao lado dos soldados norte-americanos, pergunta-se: por que o país asiático teve seu acesso negado, e os segundos, não? É o que ele põe em discussão. Numa segunda comparação, Castro nota que, enquanto EUA e China lutavam do mesmo lado, a Espanha lutava do lado oposto. Assim, conduz seus interlocutores a pensarem: por que a Espanha, que lutou em favor do fascismo, foi aceita na ONU, e a China é proibida de pertencer à 
EID\&A - Revista Eletrônica de Estudos Integrados em Discurso e Argumentação, Ilhéus, n. 15, jan./jun.2018.

organização pelo governo norte-americano? Dessa forma, o líder cubano demarca o valor refutativo de sin embargo na SD15.

\section{Considerações finais}

Através do levantamento bibliográfico de obras relacionadas à teoria da argumentação, ao dialogismo e aos estudos sobre os marcadores discursivos, observamos o grande poder de mobilização da partícula sin embargo no discurso político por meio da intervenção de Fidel Castro na Assembleia das Nações Unidas, funcionando ora para persuadir, explicar, refutar, ora para substituir um enunciado. A modo de síntese, apresentamos a tabela seguinte, que reúne os valores discursivos de sin embargo na análise da fala de Fidel Castro:

\begin{tabular}{|l|l|}
\hline Valores discursivos de sin embargo & Sequências discursivas analisadas \\
\hline Persuasão & $\begin{array}{l}\text { SD1, SD2, SD3, SD8, SD10, SD11, SD12, SD13, } \\
\text { SD14 }\end{array}$ \\
\hline Explicação refutativa & SD4, SD5, SD6, SD9, SD15 \\
\hline Substituição & SD7 \\
\hline
\end{tabular}

Com base nesse levantamento, podemos constatar uma maior recorrência à persuasão no discurso do líder cubano. Concluindo este estudo, podemos afirmar que a sua fala não teria a mesma eficácia sem o uso dos conectores contra-argumentativos. Através destes, Fidel Castro se faz compreender, levando o receptor de sua mensagem, ainda hoje, a estabelecer as relações lógico-semânticas dos enunciados que apresenta. Com isso, facilita as inferências da mensagem que ele desejava comunicar; e isso independe da aderência ou não ao seu discurso.

\section{Referências}

BAKHTIN, Mikhail (Volóchinov). Marxismo e filosofia da linguagem. 12 ed. São Paulo: HUCITEC, 2006.

CASTRO, Fidel. Discurso pronunciado por el comandante Fidel Castro Ruz, primer ministro del gobierno revolucionario, en la sede de las Naciones Unidas, Estados Unidos, el 26 de septiembre de 1960. Disponível em: http://www.cuba.cu/gobierno/discursos/1960/esp/f260960e.html Acesso em: 30 ago. 2016. 
EID\&A - Revista Eletrônica de Estudos Integrados em Discurso e Argumentação, Ilhéus, n. 15, jan./jun.2018.

FUENTES RODRÍGUEZ, Catalina. Diccionarios de conectores y operadores del español. Madrid: Arco-Libros, 2009.

FUENTES RODRÍGUEZ, Catalina; ALCAIDE Lara, Esperanza. La argumentación lingüística y sus medios de expresión. Madrid: Arco-Libros, 2007.

GARCÍA, Maria Noemí Domínguez. Conectores discursivos en textos argumentativos breves. Madrid: Arco/Libros, 2007.

MONTOLÍO, Estrella. Conectores de la lengua escrita. Barcelona: Ariel Practicum, 2001.

PORTOLÉS, José. Diferencias gramaticales y pragmáticas entre los conectores discursivos pero, sin embargo y no obstante. Boletín de la Real Academia de la Lengua Española, tomo LXXV, 1995, p. 231-270.

PORTOLÉS, José. La distinción entre los conectores y otros marcadores del discurso em español. Verba, n. 20, 1993, p.141-170.

PORTOLÉS, José. Marcadores del discurso. 2 ed. Barcelona: Ariel Practicum, 2001.

REAL ACADEMIA ESPAÑOLA. Términos lingüísticos. Disponível em: <http://www.rae.es/diccionario-panhispanico-de-dudas/> Acesso em: 11 mai. 2017.

SÁNCHEZ, Roser Martínez. Conectando texto. Guía para el uso efectivo de elementos conectores en castellano. 2 ed. Barcelona: Octaedro, 1997.

SANTOS RÍO, Luis. Diccionario de partículas (DPD). Salamanca: Luso-Española de ediciones, 2003.

SILVA FERNANDES, Ivani. Los marcadores discursivos en la argumentación escrita: estudio comparado en el espanhol y en el portugués de Brasil. Salamanca: Ediciones Universidad, 2005.

ZORRAQUINO, Martín; PORTOLÉS, José. Los marcadores del discurso. In: DEMONTE, Violeta; BOSQUE, Ignacio (Org.). Gramática descriptiva de la lengua española. Madrid: Espasa-Calpe. v. 3, 1999, p. 4051-4213.

Forma de citação sugerida:

OLIVEIRA, Ana Paula Santos de; ARAÚJo, Jacqueline Elizabeth Vásquez. A contraargumentação no discurso político: análise da primeira intervenção de Fidel Castro na ONU, 1960. EID\&A - Revista Eletrônica de Estudos Integrados em Discurso e Argumentação, Ilhéus, n. 15, p. 24-42, jan./jun.2018.

Recebido em: 31/03/2018

Aprovado em: 16/06/2018 